\title{
ANALISIS INDEKS KEPUASAN PELANGGAN TERHADAP LAYANAN PERENCANAAN, ANGGARAN, DAN PELAPORAN
}

\author{
Sri Agustini \\ Biro Perencanaan BATAN, Jakarta, Indonensia \\ agustin@batan.go.id
}

\begin{abstract}
Abstrak: Analisis Indeks Kepuasan Pelanggan Terhadap Layanan Perencanaan, Anggaran, dan Pelaporan. Penelitian ini menggunakan penelitian deskriptif dengan tujuan untuk mengetahui kepuasan masyarakat terhadap layanan BP. Hasil penilaian IKM terhadap pelayanan perencanaan, anggaran dan pelaporan di BP BATAN masuk dalam kategori Baik. Metodologi pengambilan data menggunakan data primer dan pengolahan data menggunakan metode deskriptif kualitatif dengan sampel sebanyak 534 responden dari 7 kegiatan yaitu kegiatan Penyusunan Perjanjian Kinerja (PK), Penyusunan Renstra, Perencanaan PNBP, Penyusunan RKA/KL, Revisi Anggaran, Monitoring dan Evaluasi Anggaran dan Kegiatan BATAN, dan Pelaporan Kegiatan dan Anggaran BATAN. Diperoleh nilai IKM sebesar 3,18 dengan nilai baik. Hasil analisis menunjukkan pelayanan Perencanaan, Anggaran dan pelaporan yang diberikan oleh Biro Perencanaan, dari 9 indikator diteliti ada 6 indikator dalam kategori pelayanan yang baik (biaya/tarif, maklumat pelayanan, perlaku pelaksana, kompetensi pelayanan, produk spesifikasi jenis pelayanan, dan waktu pelayanan) sementara 3 indikator lainnya tidak termasuk dalam kategori baik (pengaduan, saran, dan masukan, prosedur serta persayaratan).
\end{abstract}

Kata Kunci : Indeks Kepuasan Masyarakat, kinerja layanan, unsur pelayanan.

\begin{abstract}
Analysis of Customer Satisfaction Index on Planning, Budgeting, and Reporting Services. BATAN Planning Bureau as a government apparatus in improving the quality and performance of its services in accordance with the needs of the community, in various sectors by conducting a Customer Satisfaction survey with questionnaire dissemination techniques that are delivered to the public as service users. The results of the questionnaire can be seen the weaknesses and shortcomings in providing services to the community related to the technical guidance of planning, budgeting and reporting that are less informative, not transparent and less accommodating. This needs to be done in the planning and budgeting assessment and research in 21 BATAN work units. This study uses descriptive research with the aim to determine public satisfaction with BP services. The results of IKM's assessment of planning, budgeting and reporting services at BP BATAN are included in the Good category. Data collection methodology uses primary data and data processing uses descriptive qualitative method with a sample of 534 respondents from 7 activities, namely the preparation of Performance Agreements $(P K)$, Strategic Planning, PNBP Planning, RKA / KL Preparation, Budget Revision, Budget Monitoring and Evaluation and Activities BATAN, and BATAN Activity and Budget Reporting. The value of IKM was 3.18 with good value. The analysis shows the Planning, Budgeting and reporting services provided by the Planning Bureau, of the 9 indicators examined there were 6 indicators in the good service category (cost / tariff, service notice, implementing behavior, service competence, product specification type of service, and service time) while the other 3 indicators were not included in either category (complaints, suggestions, and input, procedures and requirements).
\end{abstract}

Keywords: Community Satisfaction Index, service performance, service elements.

\section{PENDAHULUAN}

Sejalan dengan upaya pemerintah menuju reformasi birokrasi, maka pelayanan publik menjadi salah satu tolok ukur kinerja pemerintah dalam melayani masyarakat. Kinerja pelayanan menjadi parameter yang harus diukur untuk menilai tingkat kualitas pelayanan (Wahyuningrum dan Desrianti, 2009). Pemberian pelayanan publik oleh aparatur pemerintah kepada masyarakat 
merupakan implikasi dari fungsi aparat negara sebagai pelayan masyarakat, sehingga kedudukan aparatur pemerintah dalam pelayanan umum (public services) sangat strategis. Kedudukan tersebut akan menentukan sejauhmana pemerintah mampu memberikan pelayanan yang sebaik-baiknya bagi masyarakat dan sejauhmana negara telah menjalankan perannya dengan baik sesuai dengan tujuan pendiriannya (Kartikaningdyah, 2012). Kepuasan pengguna/pelanggan merupakan evaluasi purna beli dimana alternatif yang dipilih sekurang- kurangnya memberikan hasil yang sama atau melampui harapan pengguna /pelanggan, sedangkan ketidakpuasan timbul apabila hasil yang diperoleh tidak memenuhi harapan pengguna/pelanggan (Engel dkk, 2012).

Badan Tenaga Nuklir Nasional (BATAN) sebagai lembaga negara memiliki kewajiban memberikan layanan publik secara cepat, tepat dan berkualitas kepada masyarakat agar publik dapat terlayani dengan lebih baik. Oleh karena itu, BATAN mengeluarkan Standar Pelayanan Publik yang diatur dalam Peraturan Kepala BATAN Nomor 13 tahun 2017 tentang Standar Pelayanan Publik (Peraturan Kepala BATAN Nomor 13 Tahun 2017). BATAN membuka layanan kepada masyarakat untuk mengetahui perkembangan iptek nuklir dan pemanfaatannya di berbagai bidang (industri, energi, kesehatan, maerial maju, pertanian/peternakan). BATAN sebagai aparatur pemerintah berupaya meningkatkan kualitas layanannya. Pelayanan publik yang diberikan masih banyak dijumpai kelemahan dan kekurangan, sehingga belum dapat memenuhi harapan masyarakat yang ditandai dengan banyaknya keluhan masyarakat. Kelemahan dan kekurangan tersebut dapat menimbulkan citra yang kurang baik terhadap aparatur pemerintah (Kepala BATAN Nomor: 186/KA/XII/2012 2012).

Guna mengetahui seberapa besar penilaian terhadap pelayanan yang diberikan oleh Biro Perencanaan BATAN kepada pelanggan, maka perlu dilakukan suatu pengukuran berupa tingkat kepuasan pelanggan terhadap pelayanan perencanaan, penganggaraan dan pelaporan. Biro Perencanaan (BP) BATAN perlu melakukan pengukuran indeks kepuasan masyarakat (IKM) untuk melihat seberapa besar penilaian masyarakat terhadap pelayanan yang diberikan kepada mereka terutama dalam hal pelayanan di perencanaan, penganggaran, dan pelaporan setiap tahun (Fahamsyah, 2018). Indeks Kepuasan Masyarakat (IKM) adalah data dan informasi tentang tingkat kepuasan masyarakat yang diperoleh dari hasil pengukuran secara kuantitatif dan kualitatif atas pendapat pelanggan. Oleh karena itu, BP sebagai salah satu penyelenggara pelayanan juga terus berkomitmen untuk meningkatkan kepuasan pelanggan dengan menerapkan Peraturan Kepala BATAN nomor 13 tahun 2017 tentang Standar Pelayanan Publik.

Biro Perencanaan melakukan penilaian IKM ke 21 Unit Kerja BATAN untuk 7 kegiatan. Nilai IKM dapat menjadi bahan evaluasi terhadap unsur pelayanan dalam rangka peningkatan kualitas 
pelayanan publik selanjutnya. Pelayanan kegiatan yang diberikan kepada unit kerja diantaranya adalah Penyusunan Perjanjian Kinerja (PK), Penyusunan Renstra, Perencanaan PNBP, Penyusunan RKA/KL, Revisi Anggaran, Monitoring dan Evaluasi Anggaran dan Kegiatan BATAN, dan Pelaporan Kegiatan dan Anggaran BATAN. Karena banyaknya unsur pelayanan, BP diharuskan melakukan pengukuran IKM untuk memperoleh gambaran secara obyektif mengenai kepuasan pelanggan terhadap pelayanan yang dilakukan.

Rumusan masalah pada penelitian ini adalah bagaimana IKM terhadap layanan perencanaan, anggaran dan pelaporan di BP terhadap 21 unit kerja di BATAN. Sedangkan tujuan penelitian adalah untuk mengukur IKM dan menganalisis kualitas layanan perencanaan, anggaran dan pelaporan di BP terhadap 21 unit kerja di BATAN sebagai bahan masukan dalam rangka perbaikan kinerja layanan BP.

\section{METODE}

Penelitian ini menggunakan desain penelitian deskriptif kualitatif. Penelitian deskriptif yaitu tipe yang mengumpulkan, menyusun, menginterpretasikan, dan menganalisa data sehingga memberikan keterangan lengkap mengenai perusahaan yang berkaitan dengan masalah yang dibahas (Ramadhan 2004). Pengukuran IKM Biro Perencanaan tahun 2018 mengacu pada Peraturan Kepala BATAN Nomor 13 Tahun 2017 tentang Standar Pelayanan Publik. Di dalam Peraturan tersebut mensyaratkan 9 unsur penilaian digunakan untuk menilai Pemantauan dan Evaluasi Kegiatan Litbangyasa BATAN, Penyelenggaraan PNBP, Penyusunan PK, Penyelenggaraan Raker, Penyusunan Laporan Kinerja dan Anggaran, Penyusunan RKA-KL, dan Revisi Anggaran DIPA. Survei IKM menggunakan kuesioner sebagai alat bantu pengumpulan data kepuasan masyarakat. Kuesioner disebarkan kepada 534 responden dari 7 kegiatan dari 21 unit kerja di BATAN. Kuesioner terdiri dari 9 butir pertanyaan yang berkaitan dengan unsur kepuasan yang substansinya disesuaikan dengan tujuan survei. Setiap pertanyaan memiliki 4 (empat) jawaban, namun responden hanya memilih satu jawaban yang paling tepat. Data yang diperoleh merupakan data primer, yaitu data yang diperoleh langsung dari responden melalui wawancara menggunakan kuesioner terstruktur. Data ini kemudian diolah melalui lima tahapan yakni: kodefikasi, tabulasi, kalkulasi, penilaian, dan kesimpulan.

Langkah-langkah pengolahan data dalam penghitungan nilai IKM BP adalah sebagai berikut:

a. Menginput data hasil survei/jawaban responden.

b. Menghitung Nilai Penimbang (Npe) dengan rumus berikut ini:

$$
N p e=\frac{\text { bobotsetiap unsur }}{\text { jumlah unsur }}
$$




$$
\begin{aligned}
& \text { Npe }=\frac{1}{9} \\
& \text { Npe }=0,1111
\end{aligned}
$$

c. Menghitung rata-rata dari seluruh jawaban responden atas setiap pertanyaan (RNUP).

d. Menghitung nilai indeks kepuasan dari masing-masing unsur dengan rumus berikut ini:

$$
I K U P=R N U P \times N p e
$$

c. Menghitung IKM dengan cara menjumlahkan IKUP dari 9 unsur pelayanan.

d. Melakukan konversi nilai IKM dengan rumus berikut ini:

$$
I K M \text { Konversi }=\text { Nilai } I K M \times 25
$$

e. Menginterprestasikan nilai IKM Konversi berdasarkan tabel berikut ini.

\begin{tabular}{|c|c|c|c|c|}
\hline Nilai Persepsi & $\begin{array}{c}\text { Nilai Interval } \\
\text { IKM }\end{array}$ & $\begin{array}{c}\text { Nilai Interval } \\
\text { Konversi IKM }\end{array}$ & Mutu Pelayanan & $\begin{array}{c}\text { Kerja Unit } \\
\text { Pelayanan }\end{array}$ \\
\hline 1 & $1,00-1,75$ & $25,00-43,75$ & D & Tidak Baik \\
\hline 2 & $1,76-2,50$ & $43,76-62,50$ & C & Kurang Baik \\
\hline 3 & $2,51-3,25$ & $62,51-81,25$ & B & Baik \\
\hline 4 & $3,26-4,00$ & $81,26-100,00$ & A & Sangat Baik \\
\hline
\end{tabular}

Subjek penelitian 21 Unit Kerja di lingkungan BATAN untuk 7 kegiatan dan Lokasi penelitian dilakukan di Biro Perencanaan, Kantor Pusat BATAN, Jakarta. Waktu yang diperlukan untuk menyelesaikan penelitian adalah 3 bulan.

\section{HASIL DAN PEMBAHASAN}

Biro Perencanaan melakukan koordinasi bimbingan teknis perencanaan, anggaran, dan pelaporan di seluruh unit kerja di BATAN. Penilaian unit kerja terhadap kualitas layanan BP menggunakan kuisioner. Pengukuran IKM BP tahun 2018 mengacu pada Peraturan Kepala BATAN Nomor 13 Tahun 2017 tentang Standar Pelayanan Publik. Di dalam Peraturan tersebut mensyaratkan, 9 unsur penilaian yang digunakan untuk menilai Pemantauan dan Evaluasi Kegiatan Litbangyasa BATAN, Penyelenggaraan PNBP, Penyusunan PK, Penyelenggaraan Raker, Penyusunan Laporan Kinerja dan Anggaran, Penyusunan RKA-KL, dan Revisi Anggaran DIPA. Responden berasal dari 21 unit kerja di BATAN. Jumlah responden berada pada rentang 80-90 (berbeda-beda untuk masing-masing kegiatan). Artinya, jumlah tersebut telah memenuhi jumlah minimal yang dipersyaratkan pada Perka Nomor 13 Tahun 2017 yaitu sebanyak 534 responden.

Hasil pengukuran 9 unsur Penilaian dari 534 responden untuk 7 kegiatan di 21 unit kerja. Hasil penilaian IKM untuk kegiatan Penyusunan PK BATAN Tahun 2018 unsur tertinggi pada ruang 
lingkup "Biaya/Tarif Pelayanan di Biro Perencanaan" dengan hasil penilaian responden 3,62. Sedangkan unsur terendah, ruang lingkup "Persyaratan Pelayanan di Biro Perencanaan" mencapai hasil 2,98. Hal tersebut perlu ditingkatkan kinerja layanan dari SDM BP melalui bimbingan teknis penyusunan Penetapan Kinerja (PK) dan Penyusunan Rencana Strategis (Renstra). Dapat dilihat dalam tabel 1 berikut.

Tabel 1. Penilaian IKM-Penyusunan PK BATAN Tahun 2018

\begin{tabular}{|l|l|c|c|c|c|c|c|c|c|c|c|}
\hline No & Unit Kerja & $\begin{array}{c}\text { Jumlah } \\
\text { Responden }\end{array}$ & $\mathbf{l}$ & $\mathbf{2}$ & $\mathbf{3}$ & $\mathbf{4}$ & $\mathbf{5}$ & $\mathbf{6}$ & $\mathbf{7}$ & $\mathbf{8}$ & $\mathbf{9}$ \\
\hline 1. & BU & 3 & 3,00 & 3,00 & 2,67 & 3,67 & 3,00 & 3,00 & 3,00 & 3,34 & 2,48 \\
\hline 2. & BSDMO & 5 & 2,80 & 3,20 & 2,80 & 3,20 & 3,00 & 3,33 & 3,33 & 3,33 & 3,23 \\
\hline 3. & BHHK & 4 & 3,25 & 3,25 & 3,25 & 3,75 & 3,00 & 3,25 & 3,25 & 3,63 & 3,13 \\
\hline 4. & PUSDIKLAT & 5 & 3,00 & 3,00 & 3,00 & 3,40 & 3,00 & 3,00 & 3,10 & 3,30 & 3,00 \\
\hline 5. & STTN & 1 & 3,00 & 3,00 & 3,00 & 4,00 & 3,00 & 3,00 & 3,00 & 3,00 & 3,00 \\
\hline 6. & PSMN & 1 & 3,00 & 3,00 & 3,00 & 3,00 & 3,00 & 3,00 & 3,00 & 3,00 & 3,00 \\
\hline 7. & INSPEKTORAT & 3 & 3,00 & 3,00 & 3,00 & 3,00 & 3,00 & 3,00 & 3,00 & 3,00 & 3,00 \\
\hline 8. & PAIR & 10 & 3,00 & 3,40 & 3,00 & 3,80 & 2,80 & 2,80 & 3,20 & 3,40 & 2,90 \\
\hline 9. & PSTNT & 0 & 0 & 0 & 0 & 0 & 0 & 0 & 0 & 0 & 0 \\
\hline 10. & PSTA & 5 & 3,20 & 2,80 & 3,00 & 4,00 & 3,20 & 3,00 & 3,40 & 3,60 & 3,00 \\
\hline 11. & PTKMR & 0 & 0 & 0 & 0 & 0 & 0 & 0 & 0 & 0 & 0 \\
\hline 12. & PKSEN & 5 & 3,00 & 3,00 & 3,20 & 3,20 & 3,00 & 3,00 & 3,20 & 3,00 & 3,00 \\
\hline 13. & PTLR & 5 & 2,80 & 3,00 & 3,20 & 3,80 & 3,00 & 3,00 & 3,20 & 3,30 & 3,10 \\
\hline 14. & PTRKN & 0 & 0 & 0 & 0 & 0 & 0 & 0 & 0 & 0 & 0 \\
\hline 15. & PTBBN & 5 & 2,80 & 3,00 & 2,80 & 3,80 & 2,60 & 3,00 & 3,40 & 3,60 & 2,80 \\
\hline 16. & PTBGN & 5 & 3,00 & 3,20 & 3,20 & 3,80 & 3,20 & 3,40 & 3,40 & 3,60 & 3,10 \\
\hline 17. & PPIKSN & 5 & 3,20 & 3,60 & 3,40 & 3,80 & 3,40 & 3,20 & 3,40 & 3,60 & 3,10 \\
\hline 18. & PSRG & 1 & 3,00 & 3,00 & 3,00 & 4,00 & 3,00 & 4,00 & 3,50 & 4,00 & 3,00 \\
\hline 19. & PDK & 5 & 3,40 & 3,60 & 3,20 & 3,60 & 3,20 & 3,20 & 3,50 & 3,60 & 3,00 \\
\hline 20. & PTRR & 5 & 3,00 & 3,00 & 3,00 & 3,40 & 3,00 & 3,00 & 3,10 & 3,30 & 3,00 \\
\hline 21. & PRFN & 5 & 2,30 & 2,30 & 3,40 & 4,00 & 3,20 & 3,20 & 3,60 & 3,80 & 3,20 \\
\hline TOTAL & 78 & 53,75 & 55,35 & 5,12 & 65,22 & 54,60 & 56,25 & 58,58 & 61,90 & 54,40 \\
\hline RATA-RATA & & 2,98 & 3,08 & 3,06 & 3,62 & 3,03 & 3,13 & 3,25 & 3,44 & 3,02 \\
\hline
\end{tabular}

Hasil penilaian IKM untuk kegiatan Penyusunan Renstra BATAN Tahun 2018 menunjukkan bahwa unsur tertinggi berada pada ruang lingkup "Biaya/Tarif Pelayanan di Biro Perencanaan" dengan hasil penilaian responden 3,47. Sedangkan unsur terendah adalah ruang lingkup "Produk Spesifikasi Jenis Pelayanan di Biro Perencanaan" dengan nilai hasil 2,99. Hal tersebut perlu diperjelas secara detil jenis pelayanan produk yang dihasilkan sudah sesuai dengan peraturan yang ditetapkan melalui bimbingan teknis. Hasil dapat dilihat dalam tabel 2 berikut. 
Tabel 2. Penilaian IKM - Penyusunan Renstra BATAN Tahun 2018

\begin{tabular}{|l|l|c|c|c|c|c|c|c|c|c|c|}
\hline No Unit Kerja & $\begin{array}{c}\text { Jumlah } \\
\text { Responden }\end{array}$ & $\mathbf{l}$ & $\mathbf{2}$ & $\mathbf{3}$ & $\mathbf{4}$ & $\mathbf{5}$ & $\mathbf{6}$ & $\mathbf{7}$ & $\mathbf{8}$ & $\mathbf{9}$ \\
\hline 1. & BU & 4 & 2,75 & 2,75 & 2,75 & 3,25 & 2,50 & 3,00 & 2,88 & 3,25 & 2,63 \\
\hline 2. & BSDMO & 5 & 3,00 & 3,00 & 3,20 & 3,20 & 3,00 & 3,20 & 3,30 & 3,10 & 3,00 \\
\hline 3. & BHHK & 4 & 3,00 & 3,00 & 2,75 & 3,75 & 3,00 & 3,00 & 3,00 & 3,63 & 3,13 \\
\hline 4. & PUSDIKLAT & 5 & 3,00 & 3,00 & 3,20 & 2,80 & 3,00 & 3,40 & 3,30 & 3,60 & 3,20 \\
\hline 5. & STTN & 1 & 3,00 & 3,00 & 4,00 & 4,00 & 3,00 & 4,00 & 3,50 & 3,50 & 3,50 \\
\hline 6. & PSMN & 1 & 4,00 & 4,00 & 4,00 & 4,00 & 4,00 & 4,00 & 3,50 & 4,00 & 3,50 \\
\hline 7. & INSPEKTORAT & 3 & 3,00 & 3,00 & 3,00 & 3,00 & 3,00 & 3,00 & 3,00 & 3,00 & 3,00 \\
\hline 8. & PAIR & 5 & 2,80 & 2,80 & 2,80 & 3,40 & 2,80 & 2,80 & 3,20 & 3,30 & 2,90 \\
\hline 9. & PSTA & 3 & 3,00 & 3,00 & 3,33 & 3,33 & 2,67 & 3,00 & 3,00 & 3,33 & 3,00 \\
\hline 10. & PSTNT & 5 & 3,40 & 3,20 & 3,00 & 4,00 & 3,20 & 3,00 & 3,20 & 3,50 & 2,90 \\
\hline 11. & PTKMR & 0 & 0 & 0 & 0 & 0 & 0 & 0 & 0 & 0 & 0 \\
\hline 12. & PKSEN & 5 & 2,60 & 3,00 & 3,00 & 3,00 & 3,00 & 3,00 & 3,00 & 3,00 & 2,90 \\
\hline 13. & PTLR & 5 & 2,80 & 3,00 & 2,80 & 2,80 & 2,80 & 3,00 & 3,30 & 3,40 & 3,10 \\
\hline 14. & PTRKN & 0 & 0 & 0 & 0 & 0 & 0 & 0 & 0 & 0 & 0 \\
\hline 15. & PTBBN & 4 & 2,60 & 2,40 & 2,40 & 3,20 & 2,40 & 2,40 & 3,00 & 2,70 & 2,20 \\
\hline 16. & PTBGN & 5 & 3,00 & 3,00 & 3,00 & 3,80 & 2,80 & 3,00 & 3,10 & 3,40 & 3,10 \\
\hline 17. & PPIKSN & 5 & 3,20 & 3,60 & 3,40 & 3,80 & 3,20 & 3,20 & 3,20 & 3,70 & 3,10 \\
\hline 18. & PRSG & 1 & 3,00 & 3,00 & 3,00 & 4,00 & 3,00 & 3,00 & 4,00 & 4,00 & 3,50 \\
\hline 19. & PDK & 5 & 3,00 & 3,00 & 3,60 & 3,20 & 3,20 & 3,80 & 3,20 & 3,70 & 3,10 \\
\hline 20. & PTRR & 5 & 3,20 & 3,20 & 3,00 & 3,40 & 3,20 & 3,00 & 3,20 & 3,20 & 3,00 \\
\hline 21. & PRFN & 5 & 2,80 & 3,20 & 3,40 & 4,00 & 3,00 & 3,20 & 3,50 & 3,80 & 3,40 \\
\hline & TOTAL & $\mathbf{7 6}$ & $\mathbf{5 7 , 1 5}$ & $\mathbf{5 8 , 1 5}$ & $\mathbf{5 9 , 1 3}$ & $\mathbf{6 5 , 9 3}$ & $\mathbf{5 6 , 9 7}$ & $\mathbf{6 0}$ & $\mathbf{6 1 , 3 8}$ & $\mathbf{6 5 , 1 1}$ & $\mathbf{5 7 , 9 6}$ \\
\hline & & $\mathbf{3}, 01$ & $\mathbf{3 , 0 6}$ & $\mathbf{3 , 1 1}$ & $\mathbf{3 , 4 7}$ & $\mathbf{2 , 9 9}$ & $\mathbf{3 , 1 6}$ & $\mathbf{3 , 2 3}$ & $\mathbf{3 , 4 3}$ & $\mathbf{3 , 0 5}$ \\
\hline
\end{tabular}

Hasil penilaian IKM untuk kegiatan Revisi DIPA BATAN Tahun 2018 menunjukkan bahwa unsur tinggi berada pada ruang lingkup "Biaya/Tarif Pelayanan di Biro Perencanaan" dengan hasil penilaian responden 3,49. Sedangkan unsur terendah adalah ruang lingkup "Produk Spesifikasi Jenis Pelayanan di Biro Perencanaan” dengan nilai hasil 3,09. Hal tersebut perlu diperjelas produk yang dihasilkan sudah sesuai dengan peraturan yang berlaku melalui bimbingan teknis. Hasil dapat dilihat dalam tabel 3 berikut. 
Tabel 3. Penilaian IKM - Revisi DIPA BATAN Tahun 2018

\begin{tabular}{|l|l|c|c|c|c|c|c|c|c|c|c|}
\hline No & \multicolumn{1}{|c|}{ Unit Kerja } & $\begin{array}{c}\text { Jumlah } \\
\text { Responden }\end{array}$ & $\mathbf{l}$ & $\mathbf{2}$ & $\mathbf{3}$ & $\mathbf{4}$ & $\mathbf{5}$ & $\mathbf{6}$ & $\mathbf{7}$ & $\mathbf{8}$ & $\mathbf{9}$ \\
\hline 1. & BU & 4 & 2,75 & 2,75 & 3,00 & 3,25 & 3,00 & 3,00 & 2,88 & 3,00 & 3,00 \\
\hline 2. & BSDMO & 5 & 2,80 & 3,00 & 3,00 & 3,25 & 3,00 & 3,80 & 3,25 & 3,20 & 3,00 \\
\hline 3. & BHHK & 4 & 3,00 & 3,00 & 3,00 & 3,75 & 3,25 & 3,25 & 3,00 & 2,88 & 3,00 \\
\hline 4. & PUSDIKLAT & 5 & 3,60 & 3,60 & 3,00 & 3,60 & 3,60 & 3,40 & 3,60 & 3,30 & 3,30 \\
\hline 5. & STTN & 1 & 3,00 & 3,00 & 3,00 & 3,00 & 3,00 & 3,00 & 3,00 & 3,00 & 3,00 \\
\hline 6. & PSMN & 1 & 3,00 & 3,00 & 3,00 & 3,00 & 3,00 & 3,00 & 3,00 & 3,00 & 3,00 \\
\hline 7. & INSPEKTORAT & 3 & 3,00 & 3,00 & 3,00 & 3,00 & 3,00 & 3,00 & 3,00 & 3,00 & 3,00 \\
\hline 8. & PAIR & 5 & 2,80 & 3,00 & 3,00 & 3,60 & 3,00 & 3,20 & 3,10 & 3,20 & 3,00 \\
\hline 9. & PSTNT & 5 & 3,40 & 3,40 & 3,60 & 3,40 & 3,60 & 3,60 & 3,60 & 3,80 & 3,30 \\
\hline 10. & PSTA & 5 & 3,00 & 3,00 & 3,00 & 4,00 & 3,00 & 3,00 & 3,30 & 3,00 & 3,00 \\
\hline 11. & PTKMR & 0 & 0 & 0 & 0 & 0 & 0 & 0 & 0 & 0 & 0 \\
\hline 12. & PKSEN & 5 & 3,00 & 3,00 & 3,00 & 3,00 & 3,00 & 3,00 & 2,90 & 3,00 & 3,00 \\
\hline 13. & PTLR & 5 & 3,00 & 3,00 & 3,20 & 3,80 & 3,20 & 3,20 & 3,30 & 3,30 & 3,20 \\
\hline 14. & PTRKN & 0 & 0 & 0 & 0 & 0 & 0 & 0 & 0 & 0 & 0 \\
\hline 15. & PTBBN & 4 & 3,00 & 2,80 & 3,20 & 3,20 & 2,80 & 3,20 & 3,10 & 3,10 & 3,00 \\
\hline 16. & PTBGN & 5 & 3,00 & 3,00 & 3,00 & 3,80 & 3,00 & 3,40 & 3,20 & 3,40 & 3,00 \\
\hline 17. & PPIKSN & 5 & 3,20 & 3,20 & 3,20 & 3,70 & 3,40 & 3,40 & 3,20 & 3,50 & 3,20 \\
\hline 18. & PRSG & 1 & 3,00 & 4,00 & 3,00 & 4,00 & 3,00 & 4,00 & 3,50 & 3,50 & 3,50 \\
\hline 19. & PDK & 5 & 3,00 & 3,00 & 3,00 & 3,50 & 3,00 & 3,20 & 3,10 & 3,10 & 3,10 \\
\hline 20. & PTRR & 5 & 2,80 & 3,00 & 3,00 & 3,40 & 3,00 & 3,40 & 3,20 & 3,00 & 3,00 \\
\hline 21. & PRFN & 5 & 3,00 & 3,20 & 3,00 & 3,90 & 3,00 & 3,40 & 3,40 & 3,40 & 3,10 \\
\hline TOTAL & $\mathbf{7 8}$ & $\mathbf{5 7 , 3 5}$ & $\mathbf{5 8 , 9 5}$ & $\mathbf{5 8 , 2 0}$ & $\mathbf{6 6 , 3 5}$ & $\mathbf{5 8 , 6 5}$ & $\mathbf{6 2 , 4 5}$ & $\mathbf{6 0 , 6 3}$ & $\mathbf{6 0 , 6 8}$ & $\mathbf{5 9 , 2 0}$ \\
\hline RATA-RATA & & $\mathbf{3 , 1 0}$ & $\mathbf{3 , 1 0}$ & $\mathbf{3 , 0 6}$ & $\mathbf{3 , 4 9}$ & $\mathbf{3 , 0 9}$ & $\mathbf{3 , 2 9}$ & $\mathbf{3 , 1 9}$ & $\mathbf{3 , 1 9}$ & $\mathbf{3 , 1 2}$ \\
\hline
\end{tabular}

Hasil penilaian IKM untuk kegiatan Perencanaan PNBP BATAN Tahun 2018 menunjukkan bahwa unsur tertinggi berada pada ruang lingkup "Biaya/Tarif Pelayanan di Biro Perencanaan" dengan hasil penilaian responden 3,54. Sedangkan unsur terendah adalah ruang lingkup "Prosedur Pelayanan di Biro Perencanaan" dengan nilai hasil 2,97. Hal tersebut perlu diperjelas produk yang dihasilkan telah sesuai dengan peraturan yang berlaku melalui bimbingan teknis. Hasil dapat dilihat dalam tabel 4 berikut. 
Tabel 4. Penilaian IKM - Perencanaan PNBP BATAN Tahun 2018

\begin{tabular}{|l|l|c|c|c|c|c|c|c|c|c|c|}
\hline No & \multicolumn{1}{|c|}{ Unit Kerja } & $\begin{array}{c}\text { Jumlah } \\
\text { Responden }\end{array}$ & $\mathbf{l}$ & $\mathbf{2}$ & $\mathbf{3}$ & $\mathbf{4}$ & $\mathbf{5}$ & $\mathbf{6}$ & $\mathbf{7}$ & $\mathbf{8}$ & $\mathbf{9}$ \\
\hline 1 & BU & 4 & 2,75 & 3,00 & 3,00 & 3,50 & 3,25 & 3,00 & 3,25 & 3,25 & 3,13 \\
\hline 2. & BSDMO & 0 & 0 & 0 & 0 & 0 & 0 & 0 & 0 & 0 & 0 \\
\hline 3. & BHHK & 3 & 3,00 & 3,00 & 3,00 & 4,00 & 2,67 & 3,00 & 3,17 & 3,17 & 3,00 \\
\hline 4. & PUSDIKLAT & 5 & 3,20 & 3,40 & 3,40 & 4,00 & 3,20 & 3,20 & 3,60 & 3,50 & 3,20 \\
\hline 5. & STTN & 1 & 4,00 & 3,00 & 3,00 & 4,00 & 3,00 & 3,00 & 3,50 & 3,00 & 3,50 \\
\hline 6. & PSMN & 1 & 3,00 & 4,00 & 3,00 & 4,00 & 3,00 & 4,00 & 3,50 & 4,00 & 3,50 \\
\hline 7. & INSPEKTORAT & 0 & 0 & 0 & 0 & 0 & 0 & 0 & 0 & 0 & 0 \\
\hline 8. & PAIR & 4 & 3,00 & 3,00 & 3,00 & 3,25 & 3,25 & 3,25 & 3,50 & 3,13 & 3,13 \\
\hline 9. & PSTNT & 5 & 3,60 & 3,60 & 3,60 & 3,60 & 3,60 & 3,40 & 3,60 & 3,70 & 3,50 \\
\hline 10. & PSTA & 5 & 3,20 & 3,00 & 3,00 & 3,80 & 3,00 & 3,00 & 3,10 & 3,00 & 2,90 \\
\hline 11. & PTKMR & 0 & 0 & 0 & 0 & 0 & 0 & 0 & 0 & 0 & 0 \\
\hline 12. & PKSEN & 0 & 0 & 0 & 0 & 0 & 0 & 0 & 0 & 0 & 0 \\
\hline 13. & PTLR & 5 & 2,80 & 2,80 & 3,20 & 3,80 & 3,20 & 3,00 & 3,20 & 3,10 & 3,15 \\
\hline 14. & PTRKN & 0 & 0 & 0 & 0 & 0 & 0 & 0 & 0 & 0 & 0 \\
\hline 15. & PTBBN & 4 & 2,60 & 2,60 & 2,40 & 2,80 & 2,60 & 2,60 & 2,80 & 3,00 & 3,00 \\
\hline 16. & PTBGN & 5 & 3,20 & 3,20 & 3,20 & 3,20 & 3,80 & 3,20 & 3,20 & 3,30 & 3,00 \\
\hline 17. & PPIKSN & 4 & 3,25 & 3,00 & 3,00 & 3,00 & 3,63 & 3,00 & 3,25 & 3,25 & 3,13 \\
\hline 18. & PRSG & 1 & 3,00 & 4,00 & 3,00 & 3,00 & 4,00 & 3,00 & 3,00 & 3,50 & 3,50 \\
\hline 19. & PDK & 0 & 0 & 0 & 0 & 0 & 0 & 0 & 0 & 0 & 0 \\
\hline 20. & PTRR & 5 & 2,80 & 2,80 & 3,00 & 3,40 & 3,00 & 3,20 & 3,20 & 3,10 & 3,00 \\
\hline 21. & PRFN & 5 & 2,80 & 3,00 & 3,20 & 3,70 & 3,40 & 3,40 & 3,50 & 3,40 & 3,10 \\
\hline TOTAL & $\mathbf{5 7}$ & $\mathbf{4 6 , 2 0}$ & $\mathbf{4 4 , 5 3}$ & $\mathbf{4 6}$ & $\mathbf{5 3 , 0 5}$ & $\mathbf{4 8 , 6 0}$ & $\mathbf{4 7 , 2 5}$ & $\mathbf{4 9 , 3 7}$ & $\mathbf{4 9 , 4 0}$ & $\mathbf{4 7 , 4 7}$ \\
\hline RATA-RATA & & $\mathbf{3 , 0 8}$ & $\mathbf{2 , 9 7}$ & $\mathbf{3 , 0 7}$ & $\mathbf{3 , 5 4}$ & $\mathbf{3 , 2 4}$ & $\mathbf{3 , 1 5}$ & $\mathbf{3 , 2 9}$ & $\mathbf{3 , 2 9}$ & $\mathbf{3 , 1 8}$ \\
\hline
\end{tabular}

Hasil penilaian IKM untuk kegiatan Pelaporan Kegiatan dan Anggaran BATAN Tahun 2018 menunjukkan bahwa unsur tertinggi berada pada ruang lingkup "Biaya Tarif Pelayanan di Biro Perencanaan" dengan hasil penilaian responden 3,62. Sedangkan unsur terendah yaitu ruang lingkup "Persyaratan Pelayanan di Biro Perencanaan" dengan nilai hasil 3,04. Hal tersebut perlu ditingkatkan kinerja layanan dari SDM BP melalui bimbingan teknis penyusunan Pelaporan Kegiatan dan Anggaran BATAN. Hasil dapat dilihat dalam tabel 5 berikut.

Tabel 5. Penilaian IKM - Pelaporan Kegiatan dan Anggaran BATAN Tahun 2018

\begin{tabular}{|l|l|c|c|c|c|c|c|c|c|c|c|}
\hline No Unit Kerja & $\begin{array}{c}\text { Jumlah } \\
\text { Responden }\end{array}$ & $\mathbf{l}$ & $\mathbf{2}$ & $\mathbf{3}$ & $\mathbf{4}$ & $\mathbf{5}$ & $\mathbf{6}$ & $\mathbf{7}$ & $\mathbf{8}$ & $\mathbf{9}$ \\
\hline 1. & BU & 4 & 3,00 & 3,00 & 3,00 & 4,00 & 3,25 & 3,00 & 3,00 & 3,25 & 2,75 \\
\hline 2. & BSDMO & 5 & 3,00 & 3,00 & 3,00 & 3,40 & 2,80 & 3,20 & 3,10 & 3,00 & 2,80 \\
\hline 3. & BHHK & 4 & 3,00 & 3,00 & 3,00 & 4,00 & 3,00 & 3,25 & 3,13 & 3,13 & 3,00 \\
\hline 4. & PUSDIKLAT & 5 & 3,00 & 3,20 & 3,00 & 3,80 & 3,00 & 3,00 & 3,30 & 3,20 & 3,00 \\
\hline 5. & STTN & 1 & 3,00 & 3,00 & 3,00 & 3,00 & 3,00 & 3,00 & 3,00 & 3,00 & 3,00 \\
\hline 6. & PSMN & 1 & 3.00 & 3,00 & 3,00 & 3,00 & 3,00 & 3,00 & 3,00 & 3,00 & 3,00 \\
\hline 7. & INSPEKTORAT & 3 & 3,00 & 3,00 & 3,00 & 3,00 & 3,00 & 3,00 & 3,00 & 3,00 & 3,00 \\
\hline 8 & PAIR & 10 & 3,00 & 3,10 & 3,10 & 3,85 & 3,00 & 3,10 & 3,10 & 3,30 & 3,05 \\
\hline 9. & PSTNT & 5 & 3,00 & 3,20 & 3,40 & 3,90 & 3,60 & 3,40 & 3,60 & 3,40 & 3,30 \\
\hline 10. & PSTA & 5 & 3,20 & 3,00 & 3,00 & 3,80 & 3,00 & 3,00 & 3,10 & 3,00 & 2,90 \\
\hline 11. & PTKMR & 0 & 0 & 0 & 0 & 0 & 0 & 0 & 0 & 0 & 0 \\
\hline 12. & PKSEN & 5 & 3,00 & 3,00 & 3,20 & 3,75 & 3,00 & 3,50 & 3,13 & 3,20 & 3,13 \\
\hline 13. & PTLR & 5 & 2,80 & 3,20 & 3,20 & 3,80 & 3,20 & 3,20 & 3,20 & 3,20 & 3,10 \\
\hline 14. & PTRKN & 0 & 0 & 0 & 0 & 0 & 0 & 0 & 0 & 0 & 0 \\
\hline 15. & PTBBN & 6 & 2,83 & 3,00 & 3,00 & 3,59 & 2,83 & 3,00 & 3,00 & 3,17 & 2,84 \\
\hline 16. & PTBGN & 5 & 3,00 & 3,00 & 3,20 & 3,60 & 3,40 & 3,00 & 3,30 & 3,35 & 3,10 \\
\hline 17. & PPIKSN & 5 & 3,40 & 3,40 & 3,20 & 3,80 & 3,20 & 3,20 & 3,40 & 3,40 & 3,30 \\
\hline 18. & PRSG & 1 & 3,00 & 3,00 & 4,00 & 4,00 & 4,00 & 4,00 & 3,00 & 4,00 & 3,50 \\
\hline 19. & PDK & 5 & 3,40 & 3,40 & 3,40 & 3,70 & 3,00 & 3,20 & 3,30 & 3,20 & 3,10 \\
\hline 20. & PTRR & 6 & 3,00 & 3,00 & 3,00 & 3,33 & 3,00 & 3,17 & 3,00 & 3,00 & 3,00 \\
\hline 21. & PRFN & 5 & 3,20 & 3,20 & 3,20 & 3,50 & 3,00 & 3,40 & 3,40 & 3,30 & 3,20 \\
\hline TOTAL & $\mathbf{5}$ & $\mathbf{5 7 , 8 3}$ & $\mathbf{5 8 , 7}$ & $\mathbf{5 9 , 9}$ & $\mathbf{6 8 , 8 2}$ & $\mathbf{5 9 , 2 8}$ & $\mathbf{6 0 , 6 2}$ & $\mathbf{6 0 , 0 6}$ & $\mathbf{6 1 , 1 0}$ & $\mathbf{5 8 , 0 7}$ \\
\hline RATA-RATA & & $\mathbf{3 , 0 4}$ & $\mathbf{3 , 0 9}$ & $\mathbf{3 , 1 5}$ & $\mathbf{3 , 6 2}$ & $\mathbf{3 , 1 2}$ & $\mathbf{3 , 1 9}$ & $\mathbf{3 , 1 6}$ & $\mathbf{3 , 2 2}$ & $\mathbf{3 , 0 6}$ \\
\hline
\end{tabular}


Hasil penilaian IKM untuk Monev Kegiatan dan Anggaran BATAN Tahun 2018 menunjukkan bahwa unsur tertinggi berada pada ruang lingkup "Biaya/Tarif Pelayanan di Biro Perencanaan" dengan hasil penilaian responden 3,54. Sedangkan unsr terendah yaitu ruang lingkup "Prosedur Pelayanan di Biro Perencanaan" dengan nilai hasil 3,03. Hal tersebut perlu diperjelas produk yang dihasilkan sesuai dengan peraturan yang berlaku melalui bimbingan teknis. Hasil sapat dilihat dalam tabel 6 berikut.

Tabel 6. Penilaian IKM - Monitoring dan Evaluasi Kegiatan dan Anggaran BATAN

\begin{tabular}{|c|l|c|c|c|c|c|c|c|c|c|c|}
\hline No & Unit Kerja & $\begin{array}{c}\text { Jumlah } \\
\text { Responden }\end{array}$ & $\mathbf{l}$ & $\mathbf{2}$ & $\mathbf{3}$ & $\mathbf{4}$ & $\mathbf{5}$ & $\mathbf{6}$ & $\mathbf{7}$ & $\mathbf{8}$ & $\mathbf{9}$ \\
\hline 1. & BU & 4 & 2,75 & 2,75 & 2,75 & 3,63 & 2,75 & 3,00 & 2,75 & 3,00 & 2,88 \\
\hline 2. & BSDMO & 5 & 3,00 & 2,80 & 3,00 & 3,30 & 3,40 & 3,00 & 3,00 & 3,75 & 3,00 \\
\hline 3. & BHHK & 4 & 3,00 & 3,25 & 3,25 & 4,00 & 3,25 & 3,25 & 3,25 & 3,25 & 3,00 \\
\hline 4. & PUSDIKLAT & 5 & 3,20 & 3,20 & 3,40 & 3,00 & 3,40 & 3,00 & 3,60 & 3,30 & 3,40 \\
\hline 5. & STTN & 0 & 0 & 0 & 0 & 0 & 0 & 0 & 0 & 0 & 0 \\
\hline 6. & PSMN & 1 & 3,00 & 3,00 & 3,00 & 3,00 & 3,00 & 3,00 & 3,00 & 3,00 & 3,00 \\
\hline 7. & INSPEKTORAT & 3 & 3,00 & 3,00 & 3,00 & 3,00 & 3,00 & 3,00 & 3,00 & 3,00 & 3,00 \\
\hline 8. & PAIR & 10 & 3,20 & 3,20 & 3,20 & 3,80 & 3,40 & 3,20 & 3,40 & 3,30 & 3,30 \\
\hline $9 .$. & PSTA & 5 & 3,60 & 3,20 & 3,40 & 3,60 & 3,60 & 3,40 & 3,50 & 3,50 & 3,30 \\
\hline 10. & PSTNT & 5 & 3,20 & 3,00 & 3,00 & 3,80 & 3,00 & 3,00 & 3,10 & 3,00 & 2,90 \\
\hline 11. & PTKMR & 0 & 0 & 0 & 0 & 0 & 0 & 0 & 0 & 0 & 0 \\
\hline 12. & PKSEN & 5 & 3,00 & 3,00 & 3,00 & 3,80 & 3,00 & 3,00 & 3,20 & 3,10 & 3,00 \\
\hline 13. & PTLR & 5 & 3,20 & 3,00 & 3,20 & 3,80 & 3,20 & 3,00 & 3,20 & 3,30 & 3,10 \\
\hline 14. & PTRKN & 0 & 0 & 0 & 0 & 0 & 0 & 0 & 0 & 0 & 0 \\
\hline 15. & PTBBN & 4 & 2,60 & 2,40 & 2,40 & 3,33 & 2,40 & 2,40 & 2,40 & 2,40 & 2,40 \\
\hline 16. & PTBGN & 5 & 3,20 & 3,40 & 3,00 & 3,50 & 3,40 & 3,20 & 3,30 & 3,40 & 3,10 \\
\hline 17. & PPIKSN & 5 & 3,20 & 3,40 & 3,00 & 3,60 & 3,20 & 3,40 & 3,30 & 3,50 & 3,30 \\
\hline 18. & PRSG & 1 & 3,00 & 3,00 & 4,00 & 3,50 & 4,00 & 4,00 & 3,00 & 3,50 & 3,50 \\
\hline 19. & PDK & 5 & 3,00 & 3,00 & 3,20 & 3,50 & 3,00 & 3,40 & 3,20 & 3,30 & 3,20 \\
\hline 20. & PTRR & 0 & 0 & 0 & 0 & 0 & 0 & 0 & 0 & 0 & 0 \\
\hline 21. & PRFN & 5 & 3,60 & 3,00 & 3,20 & 3,40 & 3,20 & 3,40 & 3,30 & 3,20 & 3,40 \\
\hline & TOTAL & $\mathbf{7 7}$ & $\mathbf{5 2 , 7 5}$ & $\mathbf{5 1 , 6}$ & $\mathbf{5 3}$ & $\mathbf{6 0 , 1 6}$ & $\mathbf{5 4 , 2}$ & $\mathbf{5 3 , 6 5}$ & $\mathbf{5 3 , 5 0}$ & $\mathbf{5 4 , 8}$ & $\mathbf{5 2 , 7 8}$ \\
\hline & & $\mathbf{3 , 1 0}$ & $\mathbf{3 , 0 3}$ & $\mathbf{3 , 1 1}$ & $\mathbf{3 , 5 4}$ & $\mathbf{3 , 1 9}$ & $\mathbf{3 , 1 6}$ & $\mathbf{3 , 1 5}$ & $\mathbf{3 , 2 2}$ & $\mathbf{3 , 1 0}$ \\
\hline
\end{tabular}

Hasil penilaian IKM untuk Kegiatan Penyusunan RKA/KL Tahun 2018 diperoleh kepuasan unsur tertinggi berada pada ruang lingkup "Biaya/Tarif Pelayanan di Biro Perencanaan" dengan hasil penilaian responden 3,47. Sedangkan unsur terendah yaitu ruang lingkup "Persyaratan Pelayanan di Biro Perencanaan" dengan nilai hasil 3,08. Hal tersebut perlu ditingkatkan kinerja layanan dari SDM BP melalui bimbingan teknis penyusunan RKA/KL Tahun 2018. Hasil dapat dilihat pada tabel 7 berikut. 
Tabel 7. Hasil Penilaian IKM - Kegiatan Penyusunan RKA/KL Tahun 2018

\begin{tabular}{|c|c|c|c|c|c|c|c|c|c|c|c|}
\hline No. & Unit Kerja & $\begin{array}{c}\text { Jumlah } \\
\text { Responden }\end{array}$ & 1 & 2 & 3 & 4 & 5 & 6 & 7 & 8 & 9 \\
\hline 1. & BU & 4 & 3,00 & 2,75 & 3,00 & 3,13 & 3,00 & 3,00 & 3,00 & 2,92 & 3,13 \\
\hline 2. & BSDMO & 5 & 3,00 & 2,80 & 3,00 & 3,30 & 3,40 & 3,00 & 3,00 & 3,75 & 3,00 \\
\hline 3. & BHHK & 4 & 3,00 & 3,00 & 3,25 & 4,00 & 3,25 & 3,25 & 3,00 & 3,25 & 3,00 \\
\hline 4. & PUSDIKLAT & 5 & 3,60 & 3,60 & 3,00 & 3,70 & 3,00 & 3,60 & 3,40 & 3,47 & 3,20 \\
\hline 5. & STTN & 0 & 0 & 0 & 0 & 0 & 0 & 0 & 0 & 0 & 0 \\
\hline 6. & PSMN & 1 & 3,00 & 3,00 & 3,00 & 3,00 & 3,00 & 3,00 & 3,00 & 3,00 & 3,00 \\
\hline 7. & INSPEKTORAT & 3 & 3,00 & 3,00 & 3,00 & 3,00 & 3,00 & 3,00 & 3,00 & 3,00 & 3,00 \\
\hline 8. & PAIR & 10 & 3,20 & 3,20 & 3,20 & 3,80 & 3,40 & 3,20 & 3,40 & 3,30 & 3,30 \\
\hline 9. & PSTNT & 5 & 3,60 & 3,20 & 3,40 & 3,60 & 3,60 & 3,40 & 3,50 & 3,50 & 3,30 \\
\hline 10. & PSTA & 5 & 3,20 & 3,00 & 3,00 & 3,00 & 3,00 & 3,00 & 3,10 & 3,00 & 2,90 \\
\hline 11. & PTKMR & 0 & 0 & 0 & 0 & 0 & 0 & 0 & 0 & 0 & 0 \\
\hline 12. & PKSEN & 5 & 3,40 & 3,00 & 3,00 & 3,10 & 3,20 & 3,60 & 3,00 & 3,06 & 3,20 \\
\hline 13. & PTLR & 5 & 3,00 & 3,20 & 3,20 & 3,80 & 3,40 & 3,00 & 3,20 & 3,20 & 3,10 \\
\hline 14. & PTRKN & 0 & 0 & 0 & 0 & 0 & 0 & 0 & 0 & 0 & 0 \\
\hline 15. & PTBBN & 4 & 2,80 & 3,00 & 2,80 & 3,20 & 2,80 & 3,20 & 3,00 & 3,00 & 2,80 \\
\hline 16. & PTBGN & 5 & 3,00 & 3,00 & 3,20 & 3,40 & 3,20 & 3,20 & 3,20 & 3,33 & 3,10 \\
\hline 17. & PIKSN & 5 & 3,00 & 3,20 & 3,40 & 3,75 & 3,00 & 3,20 & 3,40 & 3,33 & 3,20 \\
\hline 18. & $\begin{array}{l}\text { PRSG } \\
\end{array}$ & 1 & 2,00 & 4,00 & 4,00 & 4,00 & 4,00 & 4,00 & 4,00 & 3,67 & 3,50 \\
\hline 19. & PDK & 5 & 3,00 & 3,00 & 3,20 & 3,50 & 3,00 & 3,40 & 3,20 & 3,30 & 3,20 \\
\hline 20. & $\begin{array}{l}\text { PTRR } \\
\end{array}$ & 5 & 3,00 & 2,80 & 3,00 & 3,80 & 2,80 & 3,20 & 3,00 & 3,13 & 2,90 \\
\hline 21. & PRFN & 5 & 3,60 & 3,00 & 3,20 & 3,40 & 3,20 & 3,40 & 3,20 & 3,20 & 3,40 \\
\hline \multirow{2}{*}{\multicolumn{3}{|c|}{\begin{tabular}{c|} 
TOTAL \\
RATA-RATA
\end{tabular}}} & 55,40 & 55,75 & 56,85 & 62,48 & 57,25 & 58,65 & 57,6 & 58,4 & 56,2 \\
\hline & & & 3,08 & 3,10 & 3,16 & 3,47 & 3,18 & 3,26 & 3,20 & 3,25 & 3,12 \\
\hline
\end{tabular}

Metode pengolahan data Nilai IKM dihitung dengan menggunakan nilai rata-rata tertimbang masing-masing unsur pelayanan. Dalam penghitungan IKM terhadap 9 unsur pelayanan yang diukur, setiap unsur pelayanan memiliki penimbang yang sama, dengan rumus sebagai berikut:

Nilai Penimbang $($ Npe $)=\frac{\text { Bobot untuk setiap unsur }}{\text { Jumlah unsur }}=\frac{1}{9}=0,1111$

Berdasarkan evaluasi rangkuman tabel 1 sampai dengan 7 tersebut diatas, dapat dihitung nilai IKM dari BP sebagai berikut:

Nilai IKM $=$ Jumlah IKUP $=$ Jumlah $($ RNUP $\times$ Npe $)$

Nilai $\mathrm{IKM}=(3,04+3,06+3,10+3,54+3,12+3,19+3,21+3,29+3,09) \times 0,1111$

Nilai $\mathrm{IKM}=3,18$

Untuk memudahkan interpretasi terhadap penilaian IKM, yaitu antara 25 - 100, maka hasil penilaian tersebut di atas dikonversikan dengan nilai dasar 25, dan diperoleh Nilai IKM konversi adalah 3,18 x $25=79,5$. Berdasarkan hasil nilai IKM yang diperoleh, dapat disimpulkan bahwa Mutu Pelayanan Biro Perencanaan masuk kategori B dan kinerja Unit Pelayanan masuk kategori "Baik". Kinerja layanan BP terhadap unit kerja yang termasuk kategori "Baik" dapat dianalisis lebih lanjut dalam rangka meningkatkan nilai IKM tahun berikutnya. Nilai 9 unsur pelayanan memiliki rentang nilai minimum 3,09, sedangkan nilai maksimum 3,54 dan rata-rata 9 unsur pelayanan sebesar 3,18. Hal 
tersebut perlu ditingkatkan kinerja layanan dari SDM BP melalui bimbingan teknis. Hasil dapat dilihat pada tabel 8 dan gambar 1 berikut:

Tabel 8. Penilaian 9 Unsur Pelayanan

\begin{tabular}{|c|l|c|c|c|c|c|c|c|c|c|}
\hline \multirow{2}{*}{ No } & \multicolumn{1}{|c|}{ Kegiatan } & \multicolumn{7}{|c|}{ Masil Penilaian Pertanyaan dari 9 Unsur } \\
\cline { 3 - 11 } & \multicolumn{1}{|c|}{1} & 2 & 3 & 4 & 5 & 6 & 7 & 8 & 9 \\
\hline 1. & Penusunan PK & 2,98 & 3,08 & 3,06 & 3,62 & 3,03 & 3,13 & 3,25 & 3,44 & 3,02 \\
\hline 2. & Penyusunan Renstra & 3,01 & 3,06 & 3,11 & 3,47 & 2,99 & 3,16 & 3,23 & 3,43 & 3,05 \\
\hline 3. & Revisi DIPA & 3,02 & 3,10 & 3,06 & 3,49 & 3,09 & 3,29 & 3,19 & 3,19 & 3,12 \\
\hline 4. & Perencanaan PNBP & 3,08 & 2,97 & 3,07 & 3,54 & 3,24 & 3,15 & 3,29 & 3,29 & 3,18 \\
\hline 5. & $\begin{array}{l}\text { Pelaporan Kegiatan dan } \\
\text { Anggaran }\end{array}$ & 3,04 & 3,09 & 3,15 & 3,62 & 3,12 & 3,19 & 3,16 & 3,22 & 3,06 \\
\hline 6. & $\begin{array}{l}\text { Monev Kegiatan dan } \\
\text { Anggaran }\end{array}$ & 3,10 & 3,03 & 3,11 & 3,54 & 3,19 & 3,16 & 3,15 & 3,22 & 3,10 \\
\hline 7. & Penyusunan RKA/KL & 3,08 & 3,10 & 3,16 & 3,47 & 3,18 & 3,26 & 3,20 & 3,25 & 3,12 \\
\hline \multicolumn{1}{|c|}{ Rata-rata } & 3,04 & 3,06 & 3,10 & 3,54 & 3,12 & 3,19 & 3.21 & 3,29 & 3,09 \\
\hline
\end{tabular}

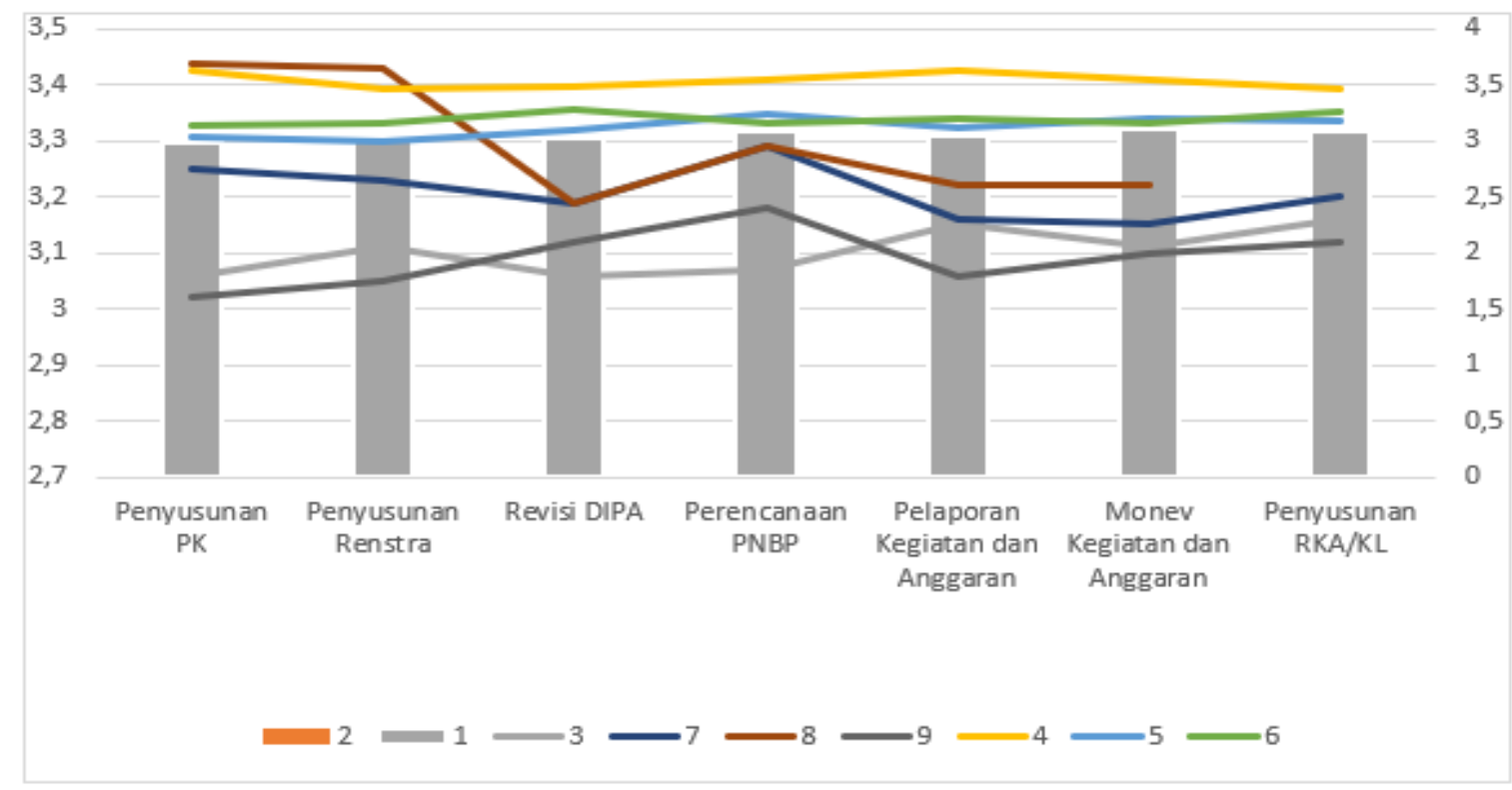

Gambar 1. Pengukuran 9 Unsur Penilaian

Berdasarkan Gambar 1, diperoleh nilai tertinggi 3,54 untuk unsur biaya/tarif. Sedangkan untuk nilai terendah ada pada unsur pengaduan, saran, dan masukan dengan nilai sebesar 3,09. Hasil survei menyimpulkan hal ini bermakna unsur pelayanan tersebut perlu untuk ditingkatkan kinerjanya. Untuk memudahkan interpretasi terhadap penilaian IKM yaitu antara 25 - 100 maka hasil penilaian tersebut di atas dikonversikan dengan nilai dasar 25. Kategori mutu pelayanan untuk setiap nilai IKM dapat dilihat pada tabel 9 dan gambar 2 berikut. 
Tabel 9. Mutu Pelayanan Nilai IKM

\begin{tabular}{|c|l|c|c|c|c|}
\hline NO & UNSUR PELAYANAN & $\begin{array}{c}\text { NILAI UNSUR } \\
\text { PELAYANAN }\end{array}$ & RATA-RATA & $\begin{array}{c}\text { NILAI } \\
\text { KONVERSI }\end{array}$ & $\begin{array}{c}\text { MUTU } \\
\text { PELAYANAN }\end{array}$ \\
\hline 1. & Persyaratan & B & 3,04 & $62,51-81,25$ & Baik \\
\hline 2. & Prosedur & B & 3,06 & $62,51-81,25$ & Baik \\
\hline 3. & Waktu Pelayanan & B & 3,10 & $62,51-81,25$ & Baik \\
\hline 4. & Biaya/Tarif & B & 3,54 & $62,51-81,25$ & Baik \\
\hline 5 & $\begin{array}{l}\text { Produk Spesifikasi } \\
\text { Jenis Pelayanan }\end{array}$ & B & 3,12 & $62,51-81,25$ & Baik \\
\hline 6. & Kompetensi Pelayanan & B & 3,19 & $62,51-81,25$ & Baik \\
\hline 7. & Perilaku Pelaksana & B & 3,21 & $62,51-81,25$ & Baik \\
\hline 8. & Maklumat Pelayanan & B & 3,29 & $62,51-81,25$ & Baik \\
\hline 9. & $\begin{array}{l}\text { Penanganan, } \\
\text { Pengaduan, Saran, dan } \\
\text { Masukan }\end{array}$ & B & 3,09 & $62,51-81,25$ & Baik \\
\hline
\end{tabular}

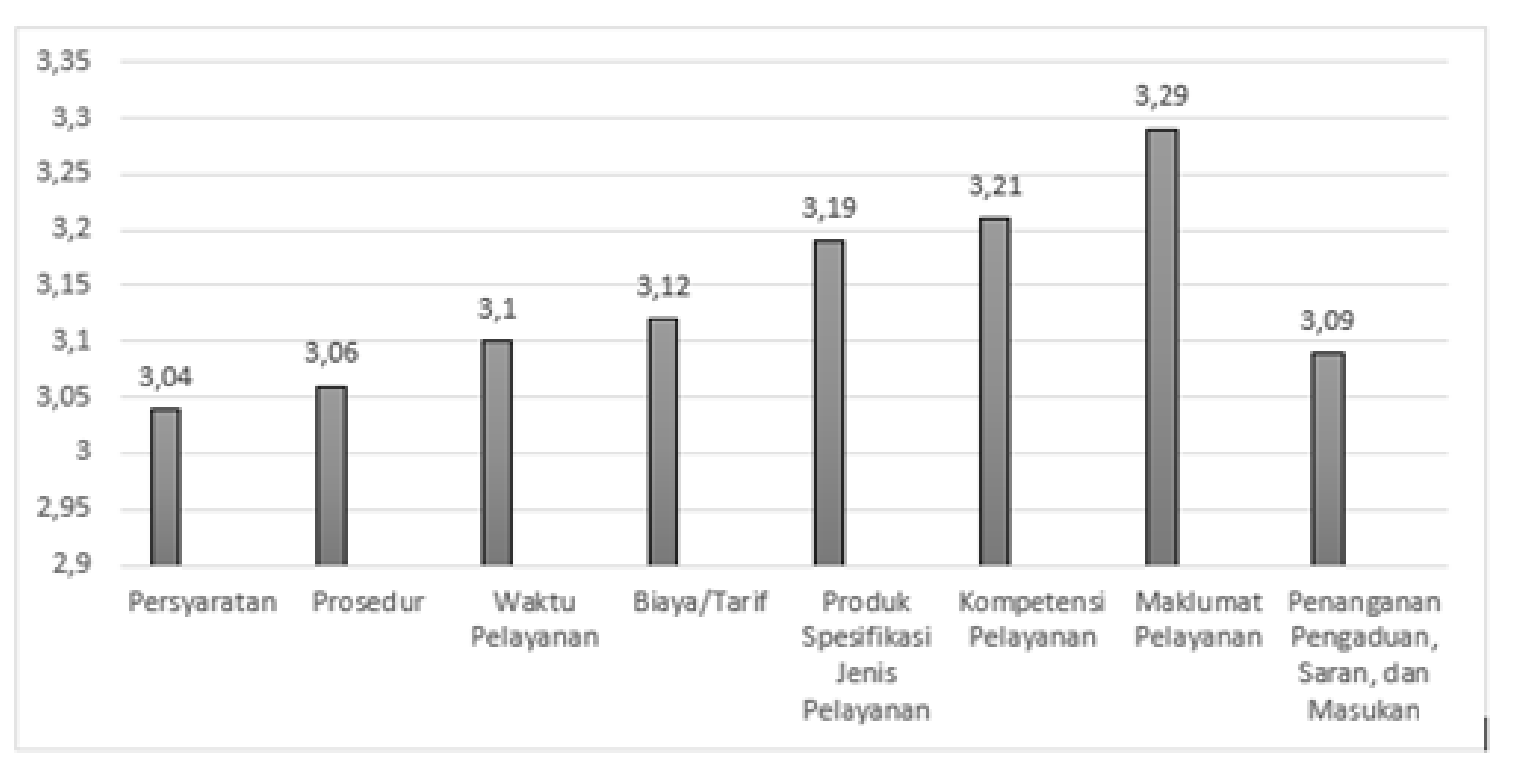

Gambar 2. Distribusi Nilai IKM Per Unsur

Perkembangan IKM BP dari tahun 2015 sampai dengan 2018 nilai IKM BP mengalami turun dan naik. Tahun 2015 dan 2016 masing-masing memperoleh nilai sebesar 3,15. Pada tahun 2017 naik dengan nilai IKM sebesar 3,22, sedangkan pada tahun 2018 turun dengan nilai 3,18. Hal tersebut disebabkan karena kurangnya layanan BP terhadap pelanggan seperti bimbingan teknis dan sosialisasi. Sebaiknya untuk yang akan datang perlu ditingkatkan kembali kinerja layanan dari semua aspek kegiatan BP. Hasil dapat dilihat pada Gambar 3 sebagai berikut: 


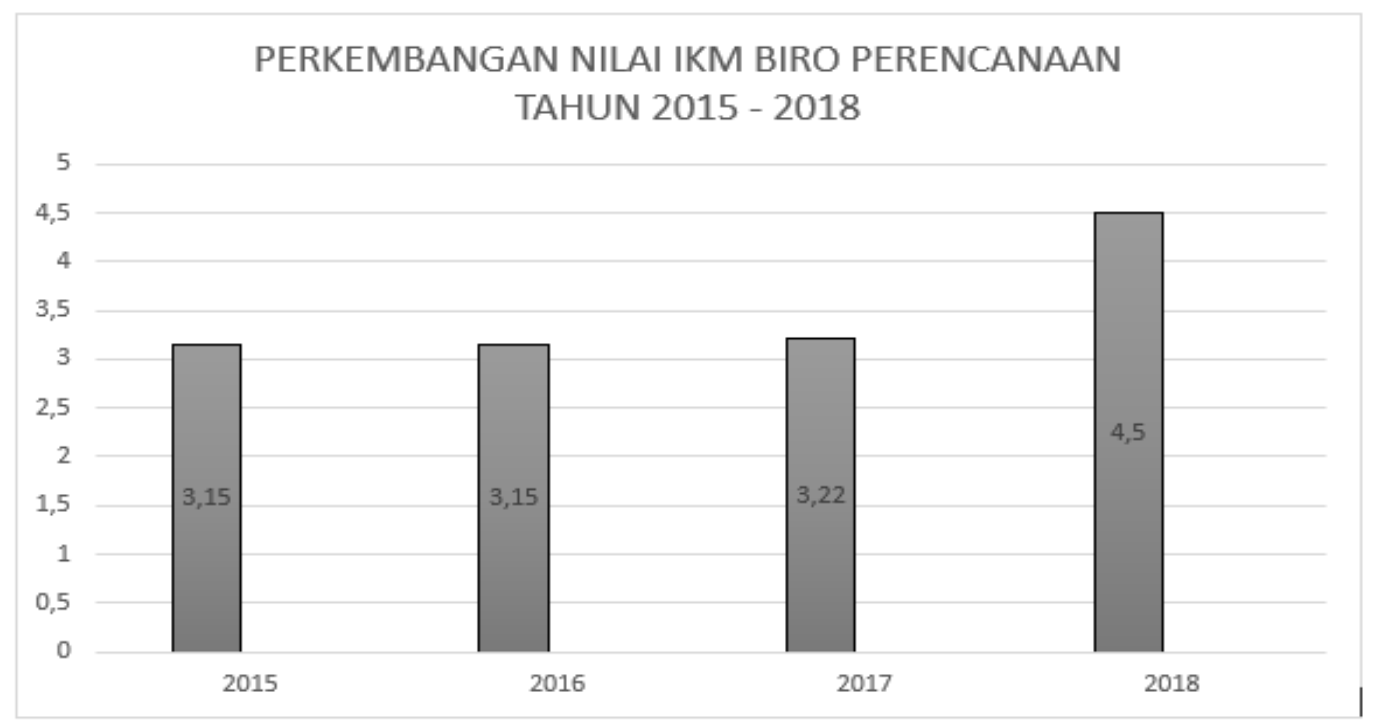

Gambar 3. Perkembangan Nilai IKM Biro Perencanaan Tahun 2015-2018

\section{KESIMPULAN}

Berdasarkan hasil penelitian yang dilakukan, diperoleh kesimpulan secara umum bahwa pelaksanaan pelayanan publik di Unit Biro Perencanaan memiliki kualitas Baik,. Hal ini terbukti nilai rata-rata dari semua unsur unsur pelayanan sebesar 3,18. Namun demikian, masih diperlukan peningkatan pelayanan terutama terkait kemampuan petugas layanan. Langkah konkret yang dilakukan oleh Biro Perencanaan pada tahun 2018 mengupayakan peningkatan Indeks Kepuasan Pelanggan dengan memberikan layanan yang lebih baik.

\section{DAFTAR PUSTAKA}

Engel, Blackwell, Miniard. (2012). Perilaku Konsumen. Tangerang: Binarupa Aksara.

Fahamsyah, Dedie. 2018. "Pengukuran Indeks Kepuasan Masyarakat (IKM) Pelayanan Kesehatan Di Puskesmas Kabupaten Hulu Sungai Utara.” Jurnal Administrasi Kesehatan Indonesia 6(2): 189.

Wahyuningrum dan O1. 2009. "Analisis Indeks Kepuasan Pelanggan Terhadap Layanan Biro Perencanaan Di Batan.”

Kartikaningdyah, Ely. 2012. “Analisis Indeks Kepuasan Masyarakat Terhadap Pelayanan Publik Pada BP2T Kota Tanjungpinang." Jurnal Integrasi 4(2): 136-47. https://jurnal.polibatam.ac.id/index.php/JI/article/view/222.

Peraturan Kepala BATAN Nomor 13 Tahun 2017 Tentang Standar Pelayanan Publik. 2017 tentang Standar Pelayan Publik. 
Ramadhan, Kurnia Dwi. Syarfan La Ode. 2004. “Analisis Laporan Keuangan Dalam Mengukur Kinerja Perusahan Pada PT. Ricky Kurniawan Kertapersada (Makin Group) Jambi.” Jurnal Valuta 2(2): 190-207.

\section{UCAPAN TERIMA KASIH}

Penulis mengucapkan terima kasih kepada kepala Biro Perencanaan dan kepala Bagian Perencanaan, Anggaran dan Evaluasi yang telah mengijinkan untuk melakukan penelitian ini. Selain itu penulis juga ingin mengucapkan terima kasih kepada rekan-rekan Tim Jaminan Mutu Perencanaan atas segala bantuan, motivasi serta dukungan, hingga selesainya artikel ini.

\section{PROFIL PENULIS}

Penulis merupakan Pegawai Negeri Sipil (PNS) Biro Perencanaan BATAN dengan jabatan fungsional perencana dengan pendidikan strata dua akuntansi perpajakan. 